\title{
The Role of Perinatal and Other Prognostic Factors in the Appearance of Brain Tumors in Childhood
}

\author{
S Plakas ${ }^{1}$, G Sfakianos ${ }^{2}$, C Tzavara ${ }^{3}$, E Papadimitriou ${ }^{4}$ and A Linos ${ }^{4 *}$ \\ ${ }^{1}$ Department of Neurosurgery, 401 General Military Hospital of Athens, Greece \\ ${ }^{2}$ Department of Neurosurgery, Agia Sofia Children's Hospital, Greece \\ ${ }^{3}$ Department of Hygiene, Centre for Health Services Research, Greece \\ ${ }^{4}$ Department of Hygiene, National and Kapodistrian University of Athens, Greece
}

Submission: November 23, 2016; Published: March 08, 2017

*Corresponding author: Athena Linos, Department of Hygiene, Epidemiology and Medical Statistics, Medical School of Athens, 75 M, Asias street, 115 27, Athens, Greece, Tel: +30 210746 2059; Fax: +30 210746 2058; Email: alinos@med.uoa.gr

\section{Abstract}

Background: Although several epidemiological studies have investigated brain tumors in children, still not much is known about their cause. In this study we investigated the role of perinatal and other prognostic factors in developing brain tumors, in childhood.

Methods: We conducted a case-control study of brain tumors in children in "Agia Sofia" Children's Hospital of Athens, Greece. Eligible subjects for the present study consisted of children from 0 to 14 years old that were either admitted or hospitalized in the Neurosurgical Clinic of "Agia Sofia" Children's Hospital between 2007 and 2012. The study questionnaire was filled in by the parents of the children.

Results: 93 children were enrolled 31 cases (32.7\%) and 62 controls (67.3). Children with brain tumors had experienced perinatal asphyxia in a significantly greater proportion compared to controls ( $p$-value $=0.039$ ). Residence location was significantly associated with the presence of tumor: children living in semi-urban/rural had almost 5 times the risk of developing a brain tumor compared to the children living in an urban area ( $p$-value $=0.010$ ). Children whose father used industrial solvents or other substances before pregnancy had more than 3.5 times the risk of developing a brain tumor compared to those whose father did not use such substances ( $p$-value $=0.011$ ). Finally, we observed an increased maternal use of mobile phones before or during pregnancy in the control group, compared to cases ( $\mathrm{p}$-value $=0.012$ ).

Conclusion: We supported that environmental factors as well as mobile phone use and working environment are key risk factors for the appearance of brain tumor in childhood.

Keywords: Brain tumours; Questionnaire; Perinatal factors; Case-control study

\section{Introduction}

Primary central nervous system neoplasm's, most of which brain located, are considered the most common solid cancer in children in developed countries, including several histologic subtypes. Brain tumors are the second most common cancer after leukemia as the leading cause of death in childhood [1]. They account for approximately $20 \%$ of newly diagnosed cases annually in the United States [2]. Although several epidemiological studies have investigated brain tumours in children, still not much is known about their causes [3-9]. Due to bimodality of the age distribution of brain tumors, and because of the significant difference in the distribution of histological types in children and adults, it is likely that different risk factors are important for children compared with adults [10]. Moreover, it has been reported that several perinatal factors play a role in the appearance of benign and malignant tumors of the central nervous system (CNS) in childhood $[1,3,11]$.

Brain tumours during childhood often occur before the age of five, suggesting that both pre- and postnatal exposures should be considered [12]. Many anthropogenic potential risk factors, with characteristics and exposures during the pregnancy as well as the postnatal period, have been previously studied; some of them yielded in inconclusive or contradictory results. For example, in terms of maternal smoking a recent large casecontrol study [12] did not find any association between maternal smoking and brain tumours in children, while Plichart et al. [13] reported similar findings. On the contrary, Brooks et al. [14] reported that children of women who smoked during pregnancy had an increased incidence of brain tumours. 
Alcohol is a known toxin for CNS. Nevertheless, a recent casecontrol study did not identify maternal alcohol consumption as a risk factor for the child [15]. Despite, previous studies reported that maternal diet and use of supplements during pregnancy, like vitamins or folic acid, did not seem to affect the potential appearance of brain tumor during childhood [16-18], many studies have suggested that prenatal vitamins are inversely related to brain tumors in child hood [19-21].

Exposure to infectious agents and/or pesticides alongside with parental occupation has showed less consistency with the appearance of brain tumour in children. These inconsistencies may be attributed to different reasons such as to heterogeneous definition of "child" in terms of age, difficulties in separating parental occupational exposure from residential history and generic definition of pesticides that does not specify certain chemical compounds [22,23].

For the case of maternal medication during pregnancy, no significant associations were found $[17,24]$ as well. A European multicenter case-control study [25] investigated whether mobile phone use is associated with brain tumor risk among children and adolescents; the authors reported that regular users of mobile phones were not statistically significantly more likely to have been diagnosed with brain tumors compared with nonusers.

Radiation exposure is probably the most studied anthropogenic factor and it has been clearly demonstrated through the years that especially radiation applied to children either for therapeutic reasons (e.g. radiotherapy for acute lymphoblastic leukemia) or diagnostic radiation exposure is associated with high and low respectively brain tumor risk [2528]. This paper describes the results of a case-control study of brain tumors in children that was conducted in "Agia Sofia" Children's Hospital of Athens, Greece between 2007 and 2012. The objectives were to investigate the role of perinatal and other prognostic factors in developing brain tumors, in childhood.

\section{Methods}

Our case-control study took place in Agia Sofia Children's Hospital of Athens, which provides neurosurgical and radiotherapy treatment for brain tumours. Its Neurosurgical Clinic is estimated to cover approximately $70-75 \%$ of children neurosurgeries in Greece and it is the only such Clinic in the country. Eligible subjects for the present study consisted of children from 0 to 14 years old that were either admitted or hospitalized in the Neurosurgical Clinic of "Agia Sofia” Children's Hospital between 2007 and 2012. Cases consisted of a random sample from children that were hospitalized and operated in the Neurosurgical Clinic for brain tumor during this period, and their parents agreed to participate in the study. The control group was randomly selected from children that were either admitted or hospitalized for head and/or brain injuries in the Neurosurgical Clinic, and their parents also agreed to participate in the study.

In terms of sample size, we aimed in acquiring a control group with a double sample size to the cases. In total 93 children were enrolled with a median age of 5.7 years. The control group consisted of $62(67.3 \%)$ children and the case group consisted of the remaining 31 (32.7\%). We used the ICCC-3 [29] definition to describe the brain tumor cases. Specifically, the case group consisted of 2 tumors ICC-3/IIIa, Ependymomas and choroid plexus tumor ( 1 choroid plexus papilloma, 1 ependymoma), 9 tumors ICC-3/IIIb, Astrocytomas (7 low grade astrocytomas \{5 hemispheric, 1 chiasmatic and 1 cerebellar\}, 2 brainstem gliomas $\{1$ malignant and 1 low-grade\}, 10 tumours ICC-3/ IIIc, Intracranial and intraspinal embryonal tumors $(9$ children with medulloblastoma, 1 hemangioblastoma), 2 tumours ICC3/ IIId, Other gliomas (2 gangliogliomas), and 7 tumours ICC$3 /$ IIIe, Other specified intracranial and intraspinal neoplasms (3 craniopharyngiomas, 1 fibrous dysplasia, 1 an plastic neurocytoma, 1 immature pituitary teratoma and 1 epidermoid tumor).One last case with tuberous sclerosis was classified in ICC-3 / IIIe, because tuberous sclerosis is a genetic syndrome that incurs a predisposition to tumors.

All cases were historically verified. After a case was identified, we contacted his/her parents and in case they agreed to participate in the study, we arranged for an interview with the child's parents where they also signed an informal consent. Interviews were conducted at the hospital by the authors. The percentage of parents in terms of their gender who responded to the questionnaire (mother/father) was $24 / 7(77.4 \% / 22.6 \%)$ for the cases and $41 / 21$, (66.1\%/33.9\%) for the controls, respectively.

The questionnaire consisted of 143 questions and contained information on demographics, residence before and during pregnancy, the delivery, prenatal and perinatal history, the maternal medical history and information on potential risk factor/behaviors (e.g. smoking habits, alcohol consumption, cell phone use, EMF radiation, medication, number of previous abortions and/or miscarriages, diet, vitamin use, diagnostic X-rays, occupational exposures, exposure to cosmetics and beauty products, exposure to insecticides, herbicides, pesticides etc.) and the paternal medical history and potential risk factor/behaviors (similarly to the maternal). Moreover, the questionnaire contained information on birth characteristics of the child, perinatal and neurosurgical history.

Normally distributed variables were expressed as mean values (SD) and non-normally distributed ones as median (min, max), while qualitative variables were expressed as absolute and relative frequencies. To investigate associations between qualitative variables, we used Pearson's chi-square or Fisher's exact tests. To compare the levels of a quantitative variable 


\section{Open Access Journal of Neurology \& Neurosurgery}

among the two groups of interest, we used either Student's t-test (for normally distributed variables) or Mann-Whitney test (for non-normally distributed variables). We used univariate logistic regression to explore which covariates were associated with the presence of tumour. All statistically significant covariates were subsequently entered in a multiple logistic regression, and the final model was determined by a stepwise procedure (entrance $\mathrm{p}$-value $=0.05$, removal $\mathrm{p}$-value $=0.10$ ) .

Statistical significance was set at a two-tailed p-value $<0.05$. All analyses were conducted in SPSS statistical software (version 19.0). In some of our results we chose to only report p-values and not 95\% confidence intervals, which give more information including the magnitude of the association and the precision, because of our small numbers of cases in some categories.

\section{Results}

Table 1: Sample characteristics, for both groups.

\begin{tabular}{|c|c|c|c|}
\hline & Controls & Cases(N=31) & \multirow{2}{*}{$(\mathbf{N}=\mathbf{6 2})$} \\
\cline { 1 - 2 } & $\mathbf{N}(\mathbf{\%})$ & $\mathbf{N}(\mathbf{\%})$ & p-value \\
\hline $\begin{array}{c}\text { Age, median } \\
\text { (range) }\end{array}$ & $5.1(0.1,14.4))$ & $4.5(0.0,14.4)$ & $0.950^{\mathrm{a}}$ \\
\hline $\begin{array}{c}\text { Mothersage, } \\
\text { mean (SD) }\end{array}$ & $37.4(4.8)$ & $36.8(6.2)$ & $0.578^{\mathrm{b}}$ \\
\hline
\end{tabular}

\begin{tabular}{|c|c|c|c|}
\hline $\begin{array}{c}\text { Fathersage, } \\
\text { mean (SD) }\end{array}$ & $40.0(6.0)$ & $41.3(7.4)$ & $0.335 \mathrm{~b}$ \\
\hline $\begin{array}{c}\text { Age during } \\
\text { pregnancy, } \\
\text { mean (SD) }\end{array}$ & $31.4(4.9)$ & $30.5(5.3)$ & $0.436^{\mathrm{b}}$ \\
\hline Gender & $39(62.9)$ & $18(58.1)$ & $0.652 \mathrm{c}$ \\
\hline Male & $23(37.1)$ & $13(41.9)$ & \\
\hline Female & $4(6.5)$ & $2(6.5)$ & $1.000^{\mathrm{d}}$ \\
\hline $\begin{array}{c}\text { Born in } \\
\text { Greece }\end{array}$ & $58(93.5)$ & $29(93.5)$ & \\
\hline No & Yes & & \\
\hline
\end{tabular}

aMann-Whitney test; 'bStudent's t-test; 'Pearson's chi-square test; dFisher's exact test

Sample characteristics are presented in Table 1. Mean age for the control group was 5.6 years (3.9) while for the case group was 5.8 years (4.4) ( $\mathrm{p}$-value $=0.950)$. The majority of children in both groups were boys, $62.9 \%$ and $58.1 \%$ for the control and case group respectively. The proportion of IVF cases was $9.7 \%$ in the case group and $4.8 \%$ in the controls group ( $\mathrm{p}=0.397)$. The two groups did not differ significantly regarding their characteristics.

Table 2: Information regarding mother's residence, for both groups.

\begin{tabular}{|c|c|c|c|c|c|c|}
\hline & \multicolumn{2}{|c|}{ Before pregnancy } & & \multicolumn{2}{|c|}{ During pregnancy } & \\
\hline & Controls & Cases & & Controls & Cases & \\
\hline & N (\%) & $\mathrm{N}(\%)$ & p-valuea & N (\%) & $\mathrm{N}(\%)$ & $\mathrm{p}$-valuea \\
\hline \multicolumn{7}{|l|}{$\begin{array}{l}\text { Region of } \\
\text { residence }\end{array}$} \\
\hline Urban & $58(93.5)$ & $21(67.7)$ & 0.002 & $56(90.3)$ & $21(67.7)$ & 0.007 \\
\hline $\begin{array}{l}\text { Semi-urban/ } \\
\text { Rural }\end{array}$ & $4(6.5)$ & $10(32.3)$ & & $6(9.7)$ & $10(32.3)$ & \\
\hline \multicolumn{7}{|l|}{ Altitude } \\
\hline $0-500 \mathrm{~m}$ & $62(100.0)$ & $25(80.6)$ & 0.001 & $62(100.0)$ & $24(77.4)$ & $<0.001$ \\
\hline$>500 \mathrm{~m}$ & $0(0.0)$ & $6(19.4)$ & & $0(0.0)$ & $7(22.6)$ & \\
\hline \multicolumn{7}{|l|}{$\begin{array}{c}\text { Bus station near } \\
\text { house }^{\mathrm{b}}\end{array}$} \\
\hline No & $53(85.5)$ & $30(96.8)$ & 0.156 & $52(83.9)$ & 30 (96.8) & 0.093 \\
\hline Yes & $9(14.5)$ & $1(3.2)$ & & $10(16.1)$ & $1(3.2)$ & \\
\hline \multicolumn{7}{|l|}{$\begin{array}{l}\text { Hospital near } \\
\text { house }^{b}\end{array}$} \\
\hline No & $54(87.1)$ & $29(93.5)$ & 0.487 & $56(90.3)$ & $29(93.5)$ & 0.714 \\
\hline Yes & $8(12.9)$ & $2(6.5)$ & & $6(9.7)$ & $2(6.5)$ & \\
\hline \multicolumn{7}{|l|}{$\begin{array}{c}\text { Railway near } \\
\text { house }^{\text {b }}\end{array}$} \\
\hline No & $49(79.0)$ & 27 (87.1) & 0.343 & $50(80.6)$ & $28(90.3)$ & 0.232 \\
\hline
\end{tabular}




\begin{tabular}{|c|c|c|c|c|c|c|}
\hline Yes & $13(21.0)$ & $4(12.9)$ & & $12(19.4)$ & $3(9.7)$ & \\
\hline \multicolumn{7}{|c|}{$\begin{array}{l}\text { Heavy transports } \\
\text { center near } \\
\text { house }^{\mathrm{b}}\end{array}$} \\
\hline No & $60(96.8)$ & $31(100.0)$ & 0.551 & $61(98.4)$ & $31(100.0)$ & 1 \\
\hline Yes & $2(3.2)$ & $0(0.0)$ & & $1(1.6)$ & $0(0.0)$ & \\
\hline \multicolumn{7}{|c|}{$\begin{array}{c}\text { Oil processing } \\
\text { or transporting } \\
\text { near house }^{\mathrm{b}}\end{array}$} \\
\hline No & 57 (93.4) & $28(90.3)$ & 0.684 & $56(91.8)$ & $28(90.3)$ & 1 \\
\hline Yes & $4(6.6)$ & $3(9.7)$ & & $5(8.2)$ & $3(9.7)$ & \\
\hline \multicolumn{7}{|c|}{$\begin{array}{c}\text { High voltage } \\
\text { power lines near } \\
\text { house }^{\text {b }}\end{array}$} \\
\hline No & $53(93.0)$ & 30 (96.8) & 0.653 & $53(93.0)$ & 30 (96.8) & 0.653 \\
\hline Yes & $4(7.0)$ & $1(3.2)$ & & $4(7.0)$ & $1(3.2)$ & \\
\hline
\end{tabular}

Table 2 presents information about the residence before and during pregnancy, by study group. A statistically significant association was found between cases and controls regarding region of residence ( $p$-value $=0.002$ before pregnancy and 0.007 during pregnancy) and altitude. Near residence sites did not differ significantly between the two study groups, although we had suggestive results for a bus station near (less than 500 meters) the residence, during pregnancy ( $\mathrm{p}$-value=0.093).

Table 3: Information regarding delivery and perinatal period, for both groups.

\begin{tabular}{|c|c|c|c|}
\hline & Controls & Cases & \\
\hline $\begin{array}{c}\text { Cephalo pelvic } \\
\text { disproportion } \\
\text { during labor }\end{array}$ & N (\%) & N (\%) & p-value \\
\hline No & $60(98.4)$ & $30(96.8)$ & $1.000^{\mathrm{a}}$ \\
\hline Yes & $1(1.6)$ & $1(3.2)$ & \\
\hline $\begin{array}{c}\text { Premature } \\
\text { rupture of the } \\
\text { amniotic sac }\end{array}$ & $61(98.4)$ & $30(96.8)$ & $1.000^{\mathrm{a}}$ \\
\hline No & $1(1.6)$ & $1(3.2)$ & \\
\hline Yes & $61(98.4)$ & $28(90.3)$ & $0.106^{\mathrm{a}}$ \\
\hline Prematurelabor & $1(1.6)$ & $3(9.7)$ & \\
\hline No & $60(96.8)$ & $26(83.9)$ & $0.039 \mathrm{a}$ \\
\hline Yes & $2(3.2)$ & $5(16.1)$ & \\
\hline Perinatal asphyxia & $23(37.1)$ & $12(38.7)$ & $0.880^{\mathrm{a}}$ \\
\hline No & $19(61.3)$ & \\
\hline Yes & & & \\
\hline Labor type & & & \\
\hline Caesarean section & & & \\
\hline Normal & & & \\
\hline
\end{tabular}

\begin{tabular}{|c|c|c|c|}
\hline Conception & & & \\
\hline Normal & $59(95.2)$ & $28(90.3)$ & $0.397^{\mathrm{a}}$ \\
\hline $\begin{array}{c}\text { Assisted } \\
\text { Reproduction }\end{array}$ & $3(4.8)$ & $3(9.7)$ & \\
\hline $\begin{array}{l}\text { Birth weight (gr), } \\
\text { mean (SD) }\end{array}$ & $3254.4(464.1)$ & $3236.9(629.8)$ & $0.902^{\mathrm{b}}$ \\
\hline \multicolumn{4}{|l|}{$\begin{array}{l}\text { Low birth weight } \\
\quad(<1500 \mathrm{gr})\end{array}$} \\
\hline No & $60(96.8)$ & $31(100.0)$ & $0.551^{\mathrm{a}}$ \\
\hline Yes & $2(3.2)$ & $0(0.0)$ & \\
\hline $\begin{array}{c}\text { Birth height }(\mathrm{cm}), \\
\text { mean }(\mathrm{SD})\end{array}$ & $51.3(2.4)$ & $50.1(4.6)$ & $0.188^{\mathrm{b}}$ \\
\hline $\begin{array}{c}\text { Head } \\
\text { circumference } \\
\text { (cm), mean (SD) }\end{array}$ & $34.1(1.2)$ & $33.6(2.3)$ & $0.302^{\mathrm{b}}$ \\
\hline
\end{tabular}

aFisher's exact test; 'btudent's t-test.

Table 3 presents results regarding labor and perinatal outcomes. As shown, children with brain tumor had experienced perinatal asphyxia in a significantly greater proportion compared to controls ( $p$-value=0.039). Labor type and type of conception did not differ significantly between the two study groups (p-values $=0.880$ and 0.337 , respectively). Family history for CNS lesions or similar abnormalities did not differ between the two groups (data not shown).

High risk behaviors of participants' parents, before and during pregnancy, are presented in Table 4. A larger proportion of fathers used industrial solvents or other substances before pregnancy in the tumor group as compared to controls, although not statistically significant. Also, in the tumor group a lower proportion of mothers used mobile phone before or during pregnancy. No significant difference was found in mothers' gynecological history, health condition during pregnancy and medical treatment, as well as parental chromosome control between the two study groups (data not shown). 


\section{Open Access Journal of Neurology \& Neurosurgery}

Table 4: Parental risk behaviors, before and during pregnancy, by group.

\begin{tabular}{|c|c|c|c|}
\hline & Controls & Cases & \\
\hline & N (\%) & N (\%) & $\mathrm{p}$-valuea \\
\hline \multicolumn{4}{|l|}{ Before pregnancy } \\
\hline \multicolumn{4}{|l|}{ Smoking (father) } \\
\hline No & $24(38.7)$ & $\begin{array}{c}10 \\
(32.3)\end{array}$ & 0.543 \\
\hline Yes & $38(61.3)$ & $\begin{array}{c}21 \\
(67.7)\end{array}$ & \\
\hline \multicolumn{4}{|l|}{$\begin{array}{c}\text { Alcoholconsumption } \\
\text { (father) }\end{array}$} \\
\hline No & $22(36.1)$ & $\begin{array}{c}15 \\
(48.4)\end{array}$ & 0.255 \\
\hline Yes & 39 (63.9) & $\begin{array}{c}16 \\
(51.6)\end{array}$ & \\
\hline \multicolumn{4}{|l|}{ Mobileuse (father) } \\
\hline No & $6(9.8)$ & $8(25.8)$ & 0.064 \\
\hline Yes & $55(90.2)$ & $\begin{array}{c}23 \\
(74.2)\end{array}$ & \\
\hline \multicolumn{4}{|l|}{$\begin{array}{l}\text { Daily duration of mobile } \\
\text { use (father) }\end{array}$} \\
\hline$<40^{\prime}$ & $27(49.1)$ & $\begin{array}{c}12 \\
(52.2)\end{array}$ & 0.804 \\
\hline$>40^{\prime}$ & $28(50.9)$ & $\begin{array}{c}11 \\
(47.8)\end{array}$ & \\
\hline \multicolumn{4}{|l|}{$\begin{array}{l}\text { Use or contact with } \\
\text { industrial solvents or } \\
\text { other substances (father) }\end{array}$} \\
\hline No & 47 (79.7) & $\begin{array}{c}16 \\
(51.6)\end{array}$ & 0.006 \\
\hline Yes & $12(20.3)$ & $\begin{array}{c}15 \\
(48.4)\end{array}$ & \\
\hline \multicolumn{4}{|l|}{ Smoking (mother) } \\
\hline No & $27(43.5)$ & $\begin{array}{c}20 \\
(64.5)\end{array}$ & 0.057 \\
\hline Yes & $35(56.5)$ & $\begin{array}{c}11 \\
(35.5)\end{array}$ & \\
\hline \multicolumn{4}{|l|}{$\begin{array}{l}\text { Alcoholconsumption } \\
\text { (mother) }\end{array}$} \\
\hline No & 37 (59.7) & $\begin{array}{c}22 \\
(71.0)\end{array}$ & 0.287 \\
\hline Yes & $25(40.3)$ & $9(29.0)$ & \\
\hline \multicolumn{4}{|l|}{ Mobileuse (mother) } \\
\hline No & $11(17.7)$ & $\begin{array}{c}13 \\
(41.9) \\
\end{array}$ & 0.012 \\
\hline Yes & $51(82.3)$ & $\begin{array}{c}18 \\
(58.1)\end{array}$ & \\
\hline \multicolumn{4}{|l|}{$\begin{array}{l}\text { Daily duration of mobile } \\
\text { use (mother) }\end{array}$} \\
\hline$<20^{\prime}$ & $23(45.1)$ & $\begin{array}{c}12 \\
(66.7) \\
\end{array}$ & 0.116 \\
\hline$>20^{\prime}$ & $28(54.9)$ & $6(33.3)$ & \\
\hline
\end{tabular}

\begin{tabular}{|c|c|c|c|}
\hline $\begin{array}{c}\text { Use or contact with } \\
\text { industrial solvents } \\
\text { or other substances } \\
\text { (mother) }\end{array}$ & & & \\
\hline No & $13(21.0)$ & $\begin{array}{c}11 \\
(35.5)\end{array}$ & 0.132 \\
\hline Yes & $49(79.0)$ & $\begin{array}{c}20 \\
(64.5)\end{array}$ & \\
\hline \multicolumn{4}{|l|}{$\begin{array}{l}\text { Maternal contact with } \\
\text { ionizing radiation }\end{array}$} \\
\hline No & $45(72.6)$ & $\begin{array}{c}25 \\
(83.3)\end{array}$ & 0.257 \\
\hline Yes & $17(27.4)$ & $5(16.7)$ & \\
\hline \multicolumn{4}{|l|}{ During pregnancy } \\
\hline \multicolumn{4}{|l|}{ Smoking (mother) } \\
\hline No & 47 (75.8) & $\begin{array}{c}24 \\
(77.4)\end{array}$ & 0.863 \\
\hline Yes & $15(24.2)$ & $7(22.6)$ & \\
\hline \multicolumn{4}{|l|}{$\begin{array}{l}\text { Alcoholconsumption } \\
\text { (mother) }\end{array}$} \\
\hline No & $54(87.1)$ & $\begin{array}{c}27 \\
(87.1) \\
\end{array}$ & 1 \\
\hline Yes & $8(12.9)$ & $4(12.9)$ & \\
\hline \multicolumn{4}{|l|}{ Mobileuse (mother) } \\
\hline No & 12 (19.4) & $\begin{array}{c}13 \\
(41.9)\end{array}$ & 0.021 \\
\hline Yes & $50(80.6)$ & $\begin{array}{c}18 \\
(58.1)\end{array}$ & \\
\hline \multicolumn{4}{|l|}{$\begin{array}{l}\text { Daily duration of mobile } \\
\text { use (mother) }\end{array}$} \\
\hline$<20^{\prime}$ & $29(58)$ & $\begin{array}{c}13 \\
(72.2)\end{array}$ & 0.287 \\
\hline$>20^{\prime}$ & $21(42)$ & $5(27.8)$ & \\
\hline \multicolumn{4}{|l|}{$\begin{array}{c}\text { Use or contact with } \\
\text { industrial solvents } \\
\text { or other substances } \\
\text { (mother) }\end{array}$} \\
\hline No & $29(49.2)$ & $\begin{array}{c}20 \\
(64.5) \\
\end{array}$ & 0.164 \\
\hline Yes & $30(50.8)$ & $\begin{array}{c}11 \\
(35.5)\end{array}$ & \\
\hline \multicolumn{4}{|l|}{$\begin{array}{l}\text { Maternal contact with } \\
\text { ionizing radiation }\end{array}$} \\
\hline No & $60(96.8)$ & $\begin{array}{c}31 \\
(100.0)\end{array}$ & 0.551 \\
\hline Yes & $2(3.2)$ & $0(0.0)$ & \\
\hline \multicolumn{4}{|l|}{$\begin{array}{l}\text { Maternal exposure to } \\
\text { drugs during pregnancy }\end{array}$} \\
\hline No & $53(85.5)$ & $\begin{array}{c}25 \\
(80.6) \\
\end{array}$ & 0.55 \\
\hline Yes & $9(14.5)$ & $6(19.4)$ & \\
\hline
\end{tabular}

aFisher's exact test. 
The results from the multiple logistic regressions are presented in Table 5. As shown, there were only two statistically significant covariates in the multiple logistic regression models, after applying the stepwise procedure. Residence location was significantly associated with the presence of tumor, with children living in semi-urban/rural having almost 5 times the risk $95 \%$ C.I.: 1.47-17.41) of developing a brain tumor compared to the children living in an urban area ( $p$-value $=0.010)$. Moreover, children whose father used industrial solvents or other substances before pregnancy had 3.62 times the risk (95\% C.I.: 1.34-9.77) of developing a brain tumor compared to those whose father did not use such substances (p-value=0.011).

Table 5: Multiple logistic regression results on the presence of brain tumor.

\begin{tabular}{|c|c|c|}
\hline & OR $(\mathbf{9 5} \% \mathbf{C I})^{\mathbf{a}}$ & p-value \\
\hline $\begin{array}{c}\text { Paternal use } \\
\text { or contact with } \\
\text { industrial solvents } \\
\text { or other substances } \\
\text { before pregnancy }\end{array}$ & & \\
\hline No & Reference & \\
\hline Yes & $3.62(1.34,9.77)$ & 0.011 \\
\hline $\begin{array}{c}\text { Residence during } \\
\text { pregnancy }\end{array}$ & & \\
\hline Urban & Reference & \\
\hline Semi-urban/ Rural & $5.06[1.47,17.41]$ & \\
\hline
\end{tabular}

aOdds Ratio (95\% Confidence Interval).

\section{Comments}

In this study we investigated the role of perinatal and other risk factors in the appearance of brain tumors in childhood. We found that children with brain tumor had experienced perinatal asphyxia in a significantly greater proportion compared to controls. Moreover, residence location was significantly associated with the presence of tumor, with children living in semi-urban/rural having almost 5 times the risk of developing a brain tumor compared to the children living in an urban area. Although altitude was significantly associated with the presence of brain tumor in the univariate analysis, it did not have a significant effect, after adjusting for other potential risk factors. Children whose father used industrial solvents or other substances before pregnancy had more than 3.5 times the risk of developing a brain tumor compared to those whose father did not use such substances. Finally, we observed an increased maternal use of mobile phones before or during pregnancy in the control group, compared to cases.

The cause of brain tumors in childhood is largely unknown [30]. A lot of studies have reported perinatal conditions as potential risk factors $[1,3,11]$. In this study we verified some of the results that have been reported in the literature, and provided evidence on potential new risk factors for brain tumors in childhood. For example, we reported an increased maternal use of mobile phones before or during pregnancy in the control group. A previous multicenter case-control study [25] conducted in Denmark, Sweden, Norway, and Switzerland did not report a statistically significantly increased risk for brain tumors in children that is associated with the use of mobile phones by them. The authors did not find a consistent exposure-response relationship either in terms of the amount of mobile phone use or by the location of the tumor. In our case, we did not have data available for the use of mobile phones from children.

We did not find a statistically significant difference on CNS family history of similar lesions or abnormalities, between the two groups. Nonetheless, statistically significant associations were found with family history of cancer and childhood brain tumors in France [31]. Specifically, the authors found that family history of cancer in general was more often reported by cases than by controls $(\mathrm{OR}=2.3,95 \%$ C.I. $=1.1-4.6)$. In their analysis, this involved a broad definition of the family to include all of the child's blood relatives.

In our study we observed a statistically significant association between tumors and residence in semi-urban/ rural region (OR: 4.63, 95\% CI: 1.12-19.12) or in a region with altitude higher than $500 \mathrm{~m}$, before and during pregnancy. Moschovi et al. [32] hypothesized that the rural place of residence in Greece is a poor prognostic indicator for brain tumors. This is probably due to delays of diagnosis or limited access to the optimal treatment facilities no and may also be supported by the possibility of increased incidence 26 of specific tumor types in children born to mothers who suffered flu during pregnancy. Towards type of residence, farm residence has been suggested by some researches $[31,33,34]$ to be a predictive factor of brain tumors in childhood. Cordier et al. [31] reported that children that their parents lives or worked in a farm during their gestational period, had an OR of 2.5 (95\% C.I.: 0.4-16.1) to develop brain tumor. If children resided in a farm during their childhood, the corresponding OR for developing a brain tumor was 6.7 (C.I.: 1.2-38.0). Five out of the seven studies included in the review by Yeni-Komshian et al. [34], examined childhood farm residence or exposure of mother or child to farm animals and, of these five, four reported elevated risk for children brain tumor with OR ranging from 0.9 to 2.5 for maternal exposures and from 0.6 to 6.7 for children's exposures. Later studies that were larger subsequently examined histological type and reported excess risk for primitive neuroectodermal tumours (PNET) with farm residence prenatally (OR=3.7, 95\% C.I. $=0.8-24)$ or in childhood $(\mathrm{OR}=5.0,95 \%$ C.I. $=1.1-4.7)$.

The present study also reported a significantly greater proportion of tumor incidents that had experienced perinatal asphyxia compared to controls. Linet et al. [35] reported that risks for all brain tumors combined were elevated in relation to characteristics of neonatal distress (a combined variable including low one-minute Apgar score, asphyxia (OR=1.5, $\mathrm{CI}=1.1$ ,2.0)) or treatments for neonatal distress (use of supplemental 


\section{Open Access Journal of Neurology \& Neurosurgery}

oxygen, ventilated on mask, use of incubator, scalp vein infusion $(\mathrm{OR}=1.6, \mathrm{CI}=0.9,2.6))$. In terms of the type of conception, we did not find a significant difference between the two study groups.

Occupation of the father and his exposure to risk factors has been surveyed much more frequently than those of the mother. In our study, high risk behaviors of the children's fathers, such as smoking, alcohol consumption or daily mobile use before pregnancy, did not differ between the two groups. Similar results have been reported in McBride et al. [32]. Paternal exposure though (use or contact) in industrial solvents or other substances (PCBs, paint products) before pregnancy was significantly higher in tumor group than the controls. The same has been observed in several studies $[9,36,37]$ that investigated the profound relationship between paternal use of petroleum products [37], painting products, solvents, pesticides and metals and excessive childhood cancer risk. This may take place through genetic changes in the ovum or sperm or through trans placental carcinogenesis [37]. Furthermore, an additional risk factor of brain tumors has been reported to be the ingestion of $\mathrm{N}$-nitroso compounds, and they have positive findings relating to increased risk for leukemia and infections [36,38,39].

One disadvantage of our study is its relatively small sample size. This was predominately determined by the relatively rare appearance of brain tumors. Our relatively small sample size along with the fact that probably different histological types have different etiologies might have limited our study power and similar considerations have been raised elsewhere [10].

\section{Conclusion}

In this study, we confirmed that environmental factors as well as mobile phone use and working environment are key risk factors for the appearance of brain tumor in childhood. Specifically, we found that maternal use of mobile phone during pregnancy as well as the paternal exposure to chemicals during work was associated with brain tumor in children.

Moreover, we reported significant association between tumors and residence in semi-urban/ rural region, and we detected a larger proportion of tumor incidents that had experienced perinatal asphyxia.

In terms of future research, we see that genomic studies that will specify genetic factors that modify brain tumor risk overall and by subtype are needed. The future for identifying etiology of childhood brain tumor lies between studies that target to identify interactions between genetic and environmental factors. Therefore, a multidisciplinary approach is vital, where clinical doctors, biochemists and epidemiologist would be mutually involved. A need also exists for availability of these samples through standardized processes to all researchers worldwide, to increase the available sample sizes.

\section{References}

1. Efird JT, Holly EA, Cordier S, Mueller BA, Lubin F, et al. (2005) Beauty product-related exposures and childhood brain tumors in seven countries: results from the SEARCH International Brain Tumor Study. J Neuro oncol 72(2): 133-147.

2. Zahm SH, Devesa SS (1995) Childhood cancer: overview of incidence trends and environmental carcinogens. Environmental Health Perspectives 103(Suppl 6): 177-184.

3. Ertel IJ (1980) Brain tumors in children. CA Cancer J Clin 30(6): 306321.

4. Johnson KJ, Cullen J, Barnholtz-Sloan JS, Ostrom QT, Langer CE, et al. (2014) Childhood brain tumor epidemiology: a brain tumor epidemiology consortium review. Cancer Epidemiol Biomarkers Prev 23(12): 2716-2736

5. Olshan AF, Breslow NE, Daling JR, Weiss NS, Leviton A (1986) Childhood brain tumors and paternal occupation in the aerospace industry. J Natl Cancer Inst 77(1): 17-19.

6. Savitz DA, John EM, Kleckner RC (1990) Magnetic field exposure from electric appliances and childhood cancer. Am J Epidemiol 131(5): 763 773.

7. Savitz DA, Feingold L (1989) Association of childhood cancer with residential traffic density. Scand J Work Environ Health 15(5): 360363.

8. Wilkins JR, Sinks T (1990) Parental occupation and intracranial neoplasms of childhood: results of a case-control interview study. Am J Epidemiol 132(2): 275-292.

9. Wilkins JR, Hundley VD (1990) Paternal occupational exposure to electromagnetic fields and neuroblastoma in offspring. Am J Epidemiol 131(6): 995-1008.

10. Howe GR, Burch JD, Chiarelli AM, Risch HA, Choi BC (1989) An exploratory case-control study of brain tumors in children. Cancer Res 49(15): 4349-4352.

11. Bunin G (2003) What causes childhood brain tumors? Limited knowledge, many clues. Pediatr Neurosurg 32(6): 321-326.

12. Vienneau D, Infangera D, Feychting M, Schuz J, Schmidt LS, et al. (2016) A multinational case-control study on childhood brain tumours, anthropogenic factors, birth characteristics and prenatal exposures: A validation of interview data. Cancer Epidemiol 40: 52-59.

13. Plichart M, Menegaux F, Lacour B, Hartmann O, Frappaz D, et al. (2008) Parental smoking, maternal alcohol, coffee and tea consumption during pregnancy and childhood malignant central nervous system tumours: the ESCALE study (SFCE). Eur J Cancer Prev 17(4): 376-383.

14. Brooks DR, Mucci LA, Hatch EE, Cnattingius S (2004) Maternal smoking during pregnancy and risk of brain tumors in the offspring. A prospective study of 1.4 million Swedish births. Cancer Causes Control 15(10): 997-1005.

15. Infante-Rivard C, El-Zein M (2007) Parental alcohol consumption and childhood cancers: a review. J Toxicol Environ Health B Crit Rev 10(12): 101-129.

16. Milne E, Greenop KR, Scott RJ, de Klerk NH, Bower C, et al. (2013) Parental alcohol consumption and risk of childhood acute lymphoblastic leukemia and brain tumors. Cancer Causes Control 24(2): 391-402.

17. Schuz J, Weihkopf T, Kaatsch P (2007) Medication use during pregnancy and the risk of childhood cancer in the offspring. Eur J Pediatr 166(5): 433-441. 


\section{Open Access Journal of Neurology \& Neurosurgery}

18. Milne E, Greenop KR, Bower C, Miller M, van Bockxmeer FM, et al. (2012) Maternal use of folic acid and other supplements and risk of childhood brain tumors. Cancer Epidemiol Biomarkers Prev 21(11): 1933-1941.

19. Greenop KR, Miller M, de Klerk NH, Scott RJ, Attia J, et al. (2014) Maternal dietary intake of folate and vitamins B6 and B12 during pregnancy and risk of childhood brain tumors. Nutr Cancer 66(5): 800-809.

20. McNeil C (1997) Vitamins during pregnancy linked to lower risk of childhood brain tumors. J Natl Cancer Inst 89(20): 1481-1482.

21. Rao GM, Rao AV, Raja A, Rao S, Rao A (2003) Plasma antioxidant vitamins in brain tumors. Neurol India 51(2): 220-222.

22. Van Maele-Fabry G, Hoet P, Lison D (2013) Parental occupational exposure to pesticides as risk factor for brain tumors in children and young adults: a systematic review and meta-analysis. Environ Int 56 19-31.

23. Efird JT, Holly EA, Preston-Martin S, Mueller BA, Lubin F, et al. (2003) Farm-related exposures and childhood brain tumours in seven countries: results from the SEARCH international brain tumour study. Paediatr Perinat Epidemiol 17(2): 201-211.

24. Kaatsch P, Scheidemann-Wesp U, Schuz J (2010) Maternal use of antibiotics and cancer in the offspring: results of a case-control study in Germany. Cancer Causes Control 21(8): 1335-1345.

25. Aydin D, Feychting M, Schüz J, Tynes T, Andersen TV, et al. (2011) Mobile phone use and brain tumors in children and adolescents: a multicenter case-control study. J Natl Cancer Inst 103(16): 1264-1276.

26. Kleinerman RA (2006) Cancer risks following diagnostic and therapeutic radiation exposure in children. Pediatric radiology 36(Suppl 2): 121-125.

27. Streffer C, Shore R, Konermann G, Meadows A, Uma Devi P, et al. (2003) Biological effects after prenatal irradiation (embryo and fetus). A report of the International Commission on Radiological, Protection. Ann ICRP 33(1-2): 205-206.

28. Boice JD, Mumma MT, Blot WJ, Heath CW (2005) Childhood cancer mortality in relation to the St Lucie nuclear power station. Journal of radiological protection 25(3): 229-240.

29. Steliarova-Foucher E, Stiller C, Lacour B, Kaatsch P (2005) International Classification of Childhood Cancer, third edition. Cancer 103(7): 14571467.

30. Linos A, Kardara M, Kosmidis H, Katriou D, Hatzis C, et al. (1998) Reported influenza in pregnancy and childhood tumour. Eur J Epidemiol 14(5): 471-475.

31. Cordier S, Iglesias MJ, Le Goaster C, Guyot MM, Mandereau L, et al. (1994) Incidence and risk factors for childhood brain tumors in the Ile de France. Int J Cancer 59(6): 776-782.

32. Moschovi M, Stavrou T, Dessypris N, Skalkidis I, Karalis D, et al. (2007) Survival among children with medulloblastoma in Greece: gains from transition to chemotherapy and socio-economic differentials. Eur J Cancer Prev 16(5): 460-465.

33. Carozza SE, Li B, Wang Q, Horel S, Cooper S (2009) Agricultural pesticides and risk of childhood cancers. Int J Hyg Environ Health 212(2): 186-195.

34. Yeni-Komshian H, Holly EA (2000) Childhood brain tumours and exposure to animals and farm life: a review. Paediatr Perinat Epidemiol $14(3):$ 248-256.

35. Linet MS, Gridley G, Cnattingius S, Nicholson HS, Martinsson U, et al. (1996) Maternal and perinatal risk factors for childhood brain tumors (Sweden). Cancer Causes Control 7(4): 437-448.

36. McBride ML (1998) Childhood cancer and environmental contaminants. Can J Public Health 89(Suppl 1): S53-S62, S58-S68.

37. Savitz DA, Chen JH (1990) Parental occupation and childhood cancer: review of epidemiologic studies. Environ Health Perspect 88: 325-337.

38. Colt JS, Blair A (1998) Parental occupational exposures and risk of childhood cancer. Environ Health Perspect 106(Suppl 3): 909-925.

39. Linos A, Kyle RA, O’Fallon WM, Kurland LT (1980) A case-control study of occupational exposures and leukemia. Cancer Causes Control 9(2): 131-135.

\section{Your next submission with Juniper Publishers will reach you the below assets}

- Quality Editorial service

- Swift Peer Review

- Reprints availability

- E-prints Service

- Manuscript Podcast for convenient understanding

- Global attainment for your research

- Manuscript accessibility in different formats

( Pdf, E-pub, Full Text, Audio)

- Unceasing customer service

Track the below URL for one-step submission

https://juniperpublishers.com/online-submission.php 